\title{
Application of Problem Based Learning Models to Students' Mathematical Problem Solving Ability
}

\author{
Agus Makmur* \\ Mathematics Study Program, Graha Nusantra University, Indonesia \\ Haritrah Hammamah Harahap \\ Mathematics Study Program, Graha Nusantra University, Indonesia \\ Susi Sulastri Lubis \\ Mathematics Study Program, Graha Nusantra University, Indonesia
}

\begin{abstract}
The research is financed by Asian Development Bank. No. 2006-A171(Sponsoring information)
\section{Abstract}

Student problem solving abilities are still low because of the lack of response of students' feedback to the teacher's questions and explanations, and the lack of concentration on mathematics. The cause of the problem is the lack of problem solving abilities of students in mathematics learning, and variations in the application of learning models. This study aims to analyze the effect of the application of problem-based learning models on mathematical problem solving abilities of students at SMAN 7 Padangsidimpuan. The type of experimental research consisted of case groups (problem based learning methods) and controls (question and answer method), with a $2 \times 3$ factorial design. The population in the study is the student at class X SMAN 7 as many as three classes with a total of as many as 34 students / class. The research samples were class X-2 and X-3, with random sampling techniques. Techniques in collecting data through tests, observations, and interviews. Statistical analysis was performed using $t$ test analysis. The results showed that the problem-based learning model was better than through the application of direct learning, with the average results of the experimental class students being 80.74 and the control class 68.24 . The application of problem-based learning to improve students' problem solving skills can be carried out by teachers in the dual improvement of the quality of education in schools.
\end{abstract}

Keywords: Problem Solving Ability, Problem Based Learning Model

DOI: $10.7176 / \mathrm{JEP} / 10-18-08$

Publication date:June $30^{\text {th }} 2019$

\section{Introduction}

The success of the learning process is largely determined by the ability of the teacher to manage the teaching and learning process. creating teaching and learning activities that are able to develop learning outcomes as much as possible is the task and responsibility of the teacher. According to Pupuh Faturohman, (2011: 13) the teacher is the spearhead in the teaching and learning process. Therefore teachers who interact directly with students in the classroom, teachers play an important role in making students understand and understand about the learning being taught. As a teacher, the teacher places more emphasis on the task in planning and implementing the learning process of learning.

Mathematics is one of the basic sciences which have an important role in efforts to master science and technology. Mathematics also has an important role in various aspects of life. There are many problems and activities in life that must be solved by using mathematical science such as counting, measuring and others.

Mathematics education in Indonesia has not revealed the expected results. The learning process of mathematics carried out by many educators today tends to achieve the target curriculum material, which is more concerned with memorizing concepts rather than understanding. Teaching is not just a process of delivering knowledge, but contains broader meanings and interactions between students and teachers. Mathematics education experts have thought and worked hard in an effort to help the younger generation become reliable problem solvers.

According to Djamarah and Aswan Zain (2010: 18) Problem solving is learning to solve problems ". At this level the students learn to formulate problem solving, provide responses to stimuli that describe or evoke problematic situations, which use a variety of rules that have been mastered.

Based on the observation of the writer that some obstacles in learning mathematics are students still confused in understanding and planning problem solving in mathematical questions so that in the implementation phase of problem solving students have difficulty getting the correct solution. In addition, students are also less capable of formulating mathematical problems to implement problem solving strategies. Students' ability to solve mathematical problems is still quite low, especially in mathematics. The results of the test analysis obtained data that the level of problem solving ability of students is still lacking. From 32 students, there are only 11 that have achieved mastery while 21 have not achieved yet and a percentage of $34 \%$ 
completeness complete and $66 \%$ not complete.

Further observations were made by researchers on Mathematics learning in SMAN 7 Padangsidimpuan which has 32 students, the teaching methods used in learning were lecture methods and expository methods. During the teaching and learning process there are students who do not pay attention to the teacher's explanation, while the learning takes place some students are sleepy, students are passive because they just sit and listen to the teacher's explanation, some students do not carry guidebooks, when the teacher asks questions, students do not answer if they are not pointed no one asks if there is material that is unclear.

Based on the above problems, it is necessary to make an innovation in mathematics learning in supporting the improvement of students' mathematical problem solving abilities. An interesting innovation that accompanied the change in paradigm was the discovery of innovative and creative learning models. According to Arends in Trianto, (2007: 68) problem-based learning is a learning approach where students work on authentic problems with the intention to develop their own knowledge, develop high-level inquiry and thinking skills, develop self-reliance and self-confidence.

With this problem-based learning students can think to solve mathematical problems and can provide motivation to students to learn math lessons (Nasution \& Lubis, 2017). Because that is what will be the goal of students' problem solving abilities that will be honed using this learning model. Mathematics presented to students in the form of problems will provide motivation for them to learn the lesson. Students will be satisfied if they can solve the problems faced with them. This intellectual satisfaction is an intrinsic gift for these students. Therefore it would be nice if mathematical activities such as finding generalizations and embedding concepts through problem solving strategies (Hudojo, 2005).

According to Faturrohman (2005: 113) Various studies on PBM have shown positive results. For example, the results of the Gijselaears study show that the application of PBM allows students to be able to identify known and needed information and strategies needed to solve problems. So, the application of PBM can improve the ability of students to solve problems.

These views finally conclude that the problem-based learning model will facilitate the success of the ability to solve real problems that occur in everyday life with real solutions, explore new fields and produce new discoveries, and interpersonal skills better than other approaches. Problem-based learning models are expected to be able to improve students' mathematical problem-solving abilities, so that students do not experience difficulties when faced with a problem related to everyday life.

Through learning by applying a problem-based learning model students are expected to learn mathematics inductively and constructively, and be able to apply problem solving with test questions and students' ability to learn mathematics. So that the authors are interested in examining the effect of the application of problem-based learning models to students' mathematical problem-solving abilities in the SMAN 7 Padangsidimpuan.

\subsection{Problem Solving}

According to Polya (1985) many referenced observers of mathematics. Polya defines problem solving as an attempt to find a way out of a difficulty in order to achieve a goal that is not immediately achievable. Sujono (1988) describes mathematical problems as challenges if their solutions require creativity, understanding and original thinking or imagination. Based on this explanation, something that is a problem for someone, may not be a problem for others or is a routine thing.

According to Ruseffendi (1991) suggests that a problem is a problem solving problem for someone if he has the knowledge and ability to solve it, but when he gets the problem he does not know how to solve it. On another occasion, Ruseffendi (1991a) also suggested that a problem is a problem for someone if: first, the problem is unknown. Second, students must be able to solve it, both their mental readiness and their ready knowledge; regardless of whether he finally arrived or not at the answer. Third, something is a problem solving for him, if he has the intention to solve it.

Problem solving is one type of intellectual skill which, according to Gagné, et al (1992) is higher in degree and more complex than other types of intellectual skills. Gagné, et al (1992) argue that in solving problems it requires complex rules or high level rules and high-level rules can be achieved after mastering defined rules and concepts. Likewise defined rules and concepts can be mastered if supported by understanding concrete concepts. After that to understand concrete concepts, skills in distinguishing are needed.

Some indicators of the ability to solve mathematical problems according to NCTM (1989: 209) are as follows:

1. Identifying the elements that are known, asked, and the adequacy of the elements needed;

2. Formulate mathematical problems or compile mathematical models;

3. Implement strategies to solve various problems (similar and new problems) within or outside mathematics;

4. Explain or interpret the results according to the original problem;

5. Use mathematics significantly. 


\subsection{Problem Based Learning Models}

Problem based learning models are a learning model that is based on the many problems that require authentic inquiry, namely investigations that require real solutions to real problems. PBL learning is an effective approach to teaching high-level thinking processes (Trianto, 2007). This learning helps students to process the information that has been made in their minds and compiles their own knowledge about the social world and its surroundings. This learning is suitable for developing basic and complex knowledge.

According to Trianto (2007) problem based learning is a learning approach in which students work on authentic problems with the intention of developing their own knowledge, developing inquiry and higher-order thinking skills, developing self-reliance and self-confidence. This learning model also refers to other learning models, such as project-based instructio ", experience-based instruction, authentic learning and anchored instruction.

\section{Method}

The type of research used in this study is experimental research The design used in this study was a $2 \times 3$ factorial design. The place of research was conducted at SMAN 7 in Padangsidimpuan. This study used two classes namely the experimental class and the control class. The experimental class has the treatment of learning using a problem-based learning model and in the control class given expository learning treatment.

Population is the overall object of research in which there are a number of subjects that can be used as data sources that are expected to provide the data needed. Arikunto (2006:130), Population is the subject of research. If someone wants to examine all the elements in their research area, the research is population research. The population in this study were all class X SMAN 7 Padangsidimpuan as many as three classes with a total of as many as 34 students / class. The sample in this study was taken by random sampling.

The research was carried out by conducting a test (pre-test) and final (post-test) given before and after using the application of problem-based learning models with direct learning. Its usefulness is to see how the improvement of students' mathematical problem solving after the application of problem-based learning models with direct learning. Data analysis used is t test analysis where previously the analysis prerequisite test was done for normality test and data homogeneity test.

\section{Results}

At the beginning of the study the two classes were given an initial ability test which aimed to determine whether the students' initial abilities in both groups were the same or not. Based on the tests that have been distributed to students, the data from the research results are grouped into three categories, namely students with high group problem solving abilities, moderate groups and low groups.

Table 1. Average Data on Initial Test Results and Final Test of Problem Solving Ability for Experimental Class Students and control classes.

\begin{tabular}{|l|l|l|l|}
\hline \multirow{2}{*}{$\begin{array}{l}\text { Problem Bearning Model } \\
\text { Lre-test }\end{array}$} & \multicolumn{4}{|l|}{ Value of Student Problem Solving Ability } \\
\cline { 2 - 4 } & High & Medium & Low \\
\hline Post-test & 85.38 & 65.83 & 48.33 \\
\hline \multirow{2}{*}{ Direct Learning Model } & 90.5 & 80 & 68.57 \\
\hline pre-test & Value of Student Problem Solving Ability \\
\cline { 2 - 4 } & High & Medium & Low \\
\hline Post-test & 81.36 & 63.21 & 47.78 \\
\hline
\end{tabular}

The results of this study indicate that the problem-based learning method shows a higher average yield to problem solving skills compared to the direct learning method. This is in line with the research of Prihatin, Iwit (2015), showing the results that there was an increase in problem solving skills after being given a problembased learning model, and an average increase in students' problem solving abilities after being given a PBM model on trapezoidal material of 0.619 in the medium category. As revealed by Pierce and Jones (Howey et al, 2001) in the implementation of problem-based learning models there are processes that must be raised, such as: engagement, inquiry and investigation, performance, question and answer and debriefing. The participation of students in the learning process aims to prepare students to act as problem solvers (self-directed problems) who can solve learning problems through collaboration with classmates, helping students encourage to be able to find problems, research and solve them. Inquiry and investigation methods include activities to explore various ways to explain and their implications, as well as collecting and distributing information. Performance aims to present the findings obtained. The question and answer discussion namely testing the accuracy of the solution and reflecting on the problem solving. Thus the problem-based learning model can help active students in solving problems given problems. 


\section{References}

Djamarah, Syaiful Bahri dan Aswan Zain. 2010. Strategi Belajar Mengajar. Jakarta: Rineka Cipta.

Fathurrohman, Muhammad. 2015. Model-Model Pembelajaran Inovatif; Alternatif Desain Pembelajaran yang Menyenangkan.Jakarta : Ar-Ruzz Media.

Faturohman, Pupuh. 2011. Mengembangkan Profesionalisme Guru: Bandung.

Gagne, R.M. 1992. The Condition of Learning and Theory of Instruction. New York: Rinehart and Winston.

Hudojo, Herman. 2005. Pengembangan Kurikulum dan Pembelajaran Matematika. Malang: Universitas Negeri Malang.

Nasution, A. \& Lukito, A. 2015. Developing Students' Proportional Reasoning Through Informal Way. Journal of Science and Mathematics Education In Southeast Asia, Vol.38 (1), pp. 77 - 101.

NCTM. 1989. Curriculum and Evaluation Standars for School Mathematics. Reston, VA: NCTM.

Polya, G. 1985. How to Solve it: A New Aspect of Mathematic Method (2nd ed. ). Princenton, New Jersey: Princenton University Press.

Ruseffendi, ET. 1991b. Pengantar Matematika Modern dan Masa Kini untuk Guru dan PGSD D2 Seri Kelima. Bandung: Tarsito.

Trianto, 2007. Model Pembelajaran Terpadu. Jakarta : PT Bumi Aksara. 